\title{
Evidences of Siderophores Synthesis by Grapevine Xylella fastidiosa, Causal Agent of Pierce's Disease, through Instrumental Approaches
}

\author{
Ana Valéria C. Simionato, ${ }^{*, a, c, d}$ Maria Estela Silva-Stenico, ${ }^{b}$ \\ Siu Mui Tsai ${ }^{b}$ and Emanuel Carrilho ${ }^{c, d}$
}
${ }^{a}$ Grupo de Toxicologia de Alimentos e Fármacos, Universidade Estadual de Campinas, P.O.Box 6154, 13083-970 Campinas-SP, Brazil

${ }^{b}$ Laboratório de Biologia Celular e Molecular, Centro de Energia Nuclear na Agricultura, Universidade de São Paulo, Av. Centenário, 303, CP 96, 13416-000 Piracicaba-SP, Brazil

${ }^{c}$ Grupo de Bioanalítica, Microfabricação e Separações, Instituto de Química de São Carlos, Universidade de São Paulo, Av. Trab. São-Carlense, 400 CP 780, 13560-970 São Carlos-SP, Brazil

${ }^{d}$ Instituto Nacional de Ciência e Tecnologia em Bioanalítica, Universidade Estadual de Campinas, CP 6154, 13083-970 Campinas-SP, Brazil

\begin{abstract}
Os sideróforos provenientes de Xylella fastidiosa de videiras foram investigados. Tais metabólitos seqüestram ferro, um elemento essencial, do hospedeiro, o que os torna um potencial fator de patogenicidade. Em um meio de cultura em placa com limitação de ferro, tais sideróforos foram detectados pela reação com o complexo cromoazurol S (CAS). Diferentes métodos de análise instrumentais foram utilizados para caracterização dos sideróforos, como: cromatografia de afinidade por metal imobilizado (IMAC), cromatografia micelar eletrocinética capilar (MEKC) e espectrometria de massas com ionização por electrospray (ESI-MS). Os resultados obtidos confirmaram a produção de sideróforos. A extração do(s) composto(s) por IMAC com $\mathrm{Fe}^{3+}$ imobilizado foi uma etapa importante. $\mathrm{O}(\mathrm{s})$ sideróforo(s) não foi separado por eletroforese capilar de zona, indicando sua neutralidade sob os pHs investigados. As análises por MEKC apresentaram um pico diferente (quando comparadas à análise do controle), com caráter levemente hidrofóbico. A espectrometria de massas mostrou que os compostos alvos podem ter uma massa molecular relativa dentro da esperada para sideróforos, como: 875, 1004 e 1092 Da.
\end{abstract}

Siderophore molecules from grapevine Xylella fastidiosa were investigated. Such metabolites sequester iron, an essential element, from the host, making them a potential factor of pathogenicty. In an iron-limited medium, siderophores were detected in culture plates of $X$. fastidiosa containing the complex Chromeazurol S (CAS). A combination of different instrumental analyses was used for siderophore(s) characterization, such as: immobilized metal affinity chromatography (IMAC), micelar electrokinetic capillary chromatography (MEKC) and electrospray-mass spectrometry (ESI-MS). The results show that grapevine $X$. fastidiosa produced siderophore(s), as confirmed by the CAS plate assay. The extraction of the compound(s) using IMAC with immobilized $\mathrm{Fe}^{3+}$ was important for analyte purification. The chelator was not separated by capillary zone electrophoresis, indicating the possibility of a neutral compound under the investigated $\mathrm{pHs}$. MEKC runs presented a different peak (when compared to the control analysis) which represented a slightly hydrophobic compound. Mass spectrometry showed that the compound(s) may have a relative molecular mass within the expected range for siderophore molecules, such as 875, 1004 and 1092 Da.

Keywords: IMAC, MEKC, ESI-MS, siderophores, iron sequestration

\section{Introduction}

Xylella fastidiosa is a gram-negative pathogenic bacterium in grapevine, resulting in Pierce's disease, and

*e-mail: avsimionato@iqm.unicamp.br in a large variety of other hosts. Many diseases are caused by $X$. fastidiosa, citrus variegated chlorosis $(\mathrm{CVC})^{3}$ and Pierces' disease of grapevine (PD) $)^{2,3}$ being economically the most important ones. Other diseases caused by this phytopathogen are found in the following hosts: peach, plum, ${ }^{5}$ coffee, ${ }^{6}$ almond, sycamore, alfalfa, among others. 
CVC has been an economical problem in Brazil towards production of orange, while Pierce's disease has been the major concern in USA, therefore both countries have tried to control such diseases. ${ }^{8}$

The complete genome of Xylella fastidiosa (citrus strain 9a5c) has been sequenced by a Brazilian consortium. ${ }^{9}$ It was the first pathogenic phytobacterium with a sequenced genome in the world. By X. fastidiosa genome inspection, five outer membrane receptors - associated to iron transportation - have been recognized and about 67 genes are involved in iron metabolism. ${ }^{9}$

Siderophores are low molecular mass chelators that guarantees iron uptake to several microorganisms. ${ }^{10}$ Besides iron, other metals may also complex with siderophores and most of them present the following affinities: $\mathrm{Ca}^{2+}<\mathrm{Ni}^{2+}<\mathrm{Zn}^{2+}<\mathrm{Cu}^{2+}<\mathrm{Al}^{3+}<\mathrm{Fe}^{3+}$ (i.e., $\mathrm{Fe}^{3+}$ and $\mathrm{Ca}^{2+}$ have the strongest and the weakest complex stability, respectively). ${ }^{11,12}$ Different molar ratios may be observed according to the metal-siderophore complex, while $\mathrm{Fe}^{3+}$ complexes present a higher formation constant $\left(\mathrm{K}_{\mathrm{f}}=10^{13}\right)$, than $\mathrm{Fe}^{2+}\left(\mathrm{K}_{\mathrm{f}}=104\right)$ and $\mathrm{Ni}^{2+}$ (data not presented by the authors).$^{13}$ Iron, as found in the environment, is highly insoluble; therefore, siderophores are secreted by microorganisms to complex iron and transport it into the cell. Because siderophore- $\mathrm{Fe}^{3+}$ is found at very low concentrations outside cells, diffusion through outer membrane would not suffice to supply the necessary uptake for this element. Therefore, a system of outer membrane high affinity siderophores receptors (probably similar to that recognized in X. fastidiosa genome) is required in order to transport the complex into the periplasma. ${ }^{14,15}$

In general, siderophores may be classified as: cathecolates, ${ }^{16}$ hydroxamates,${ }^{17}$ phenolics ${ }^{18}$ and carboxylates, ${ }^{19}$ or a combination of them. Hydroxamates and cathecolates siderophores present different mechanisms of iron release. ${ }^{20}$ The amino acid composition of such molecules, which are synthesized non-ribossomicaly, may be predicted with the aid of molecular tools. ${ }^{21}$

Literature reports some of the most used siderophores bioassays, ${ }^{22}$ including Arnow assay for cathecolates, ${ }^{23}$ Csáky assay for hydroxamates, ${ }^{24}$ and Chrome Azurol $\mathrm{S}$ (CAS), ${ }^{25}$ which is used as an universal assay, since it does not classify the functional group of the detected siderophore. The CAS test is based on the reaction of a ligand added to the media containing siderophore, which shows a change of color from blue to orange in the presence of a siderophore. In solid plate cultures containing low concentration of $\mathrm{Fe}^{3+}$, in order to activate the bacterium metabolism of siderophores synthesis, CAS assay results in orange halos around bacteria isolates (equation 1).

$$
\begin{array}{ll}
\mathrm{FeDye}^{3-\lambda}+L^{\kappa-} \rightarrow \mathrm{FeL}^{3-\kappa} & +\mathrm{Dye}^{\lambda-} \\
\text { blue } & \text { orange }
\end{array}
$$

Capillary electrophoresis (CE) is a fast and efficient separation method, which has been extensively used in biomolecules analyses. ${ }^{26-28}$ Therefore, the application of $\mathrm{CE}$ in siderophore analyses is a promising field, since these analytes are found in very complex media, such as biological matrixes or microbial cultures. Within the several CE separation modes, micellar electrockinetic capillary chromatography (MEKC) is probably the most suitable one, as soon as siderophores with different hydrophobic properties are currently known. Besides, a simple preparation step is required before siderophore CE analyses. Mucha et al..$^{29}$ have analyzed siderophores by $\mathrm{CE}$ after isolation of the analytes by filtration followed by adsorption on ionic exchange column. ${ }^{29}$

High performance liquid chromatography (HPLC) coupled to electrospray mass spectrometry (LC-ESI-MS and LC-ESI-MS/MS) is an efficient tool towards separation and identification of siderophores. ${ }^{30,31}$ Cox et al. ${ }^{32}$ extracted siderophores from culture supernatants by liquid extraction using ethyl acetate. The authors observed that cultivation time and iron deficiency conditions were critical factors in siderophores production, as observed in the HPLC chromatograms profiles. Electrospray ionizationmass spectrometry has also been used for the study of hydroxamate siderophores. ${ }^{33,34}$

Immobilized metal affinity chromatography (IMAC) is a sample preparation / separation technique based on affinity of some proteins to immobilized metals. ${ }^{35}$ IMAC is mainly used for purification of proteins, but lately it has also been used for immobilized metal ion affinity capillary electrophoresis, among other applications. ${ }^{35,36}$ IMAC, first introduced by Porath, ${ }^{37}$ has gained wide acceptance simultaneously to its development. Briefly, A metal ion (Lewis acid) is immobilized to a support matrix. The incoming protein binds to the immobilized metal and separates from the rest of the sample. Elution of protein can be carried out by different mechanisms. ${ }^{38,39} \mathrm{Fe}^{3+}$ hydroxamate has already been used as IMAC adsorbent. $\mathrm{Fe}^{3+}$ exists in solution in the hexacoordinated form. Therefore, when it is immobilized, some of its coordination sites are occupied by fixed ligands from the polymeric matrix. ${ }^{40}$ Thus, $\mathrm{Fe}^{3+}$ immobilization on IMAC columns may be successfully used in extraction of siderophores from complex samples.

Van Sluys et al. ${ }^{41}$ compared the genome sequences from Pierce's disease and Citrus Variegated Chlorosis strains of X. fastidiosa. They have concluded that $98 \%$ of such genes are essentially the same in both genomes, indicating 
that both strains present identical metabolic functions and most probably the same colonization and pathogenesis mechanisms. Bioassays and MS analyses strongly suggests that citrus $X$. fastidiosa secrets siderophores but their structures have not been elucidated yet. ${ }^{42,43}$ Some studies have also shown that $X$. fastidiosa in vitro growth is aided by the presence of producing siderophores endophytic bacteria, such as Methylobacterium. Lacava et al. ${ }^{44}$ have concluded that $X$. fastidiosa is able to use such siderophores as iron source. Therefore, the genome evidences of siderophore receptors and the ability of $X$. fastidiosa to use siderophores, suggests the potentiality of such metabolites in the plant pathogenicity process. Accordingly grapevine $X$. fastidiosa must also secret siderophores. Therefore, investigations of such siderophores have been carried out herein by: i) sample extraction from solid plate-CAS culture media; ii) isolation of the analyte by IMAC; iii) and characterization by MEKC and electrospray MS.

\section{Experimental}

\section{Materials}

Acetonitrile, acetone, ammonium hydroxide, EDTA and sodium phosphate salts (analytical grade) were purchased from Mallinckrodt (Paris - USA or Xalostoc - Mexico). Sodium dodecyl sulfate was acquired from Polysciences (Warrington - USA). Formic acid and phosphoric acid $(85 \%)$ was purchased from Merck (Rio de Janeiro - Brazil) and $\mathrm{NaOH}$ was from Synth (Diadema - Brazil). $\mathrm{Fe}_{2}\left(\mathrm{SO}_{4}\right)_{3}$ was purchased from Riedel-de Häen (Seelze - Germany) and Chrome azurol $\mathrm{S}$ was acquired from Aldrich (Steinheim - Germany) and its solution was prepared according to Schwyn \& Neilands..$^{25}$ All solutions were prepared with purified water obtained from a Milli-Q system (Millipore, Bedford - USA).

\section{Bacterial strain and growth conditions}

Grapevine X. fastidiosa (strain 6752) was obtained from INRA - Institut National de la Recherche Agronomique et Universite' Victor Se'gale (Bordeaux - France). Bacteria were cultured three times in an iron-deficient agar medium (MM9) containing the complex Chrome Azurol S plus $\mathrm{Fe}^{3+}$, according to Silva-Stenico et al. ${ }^{42}$ Positive results were recorded as a halo formation around the colonies.

\section{Sample preparation}

An agar block $\left(\mathrm{ca} .1 \mathrm{~cm}^{2}\right)$ excised from the halo region was used for analysis and a corresponding agar block, in which no bacterial growth was observed, was used as negative control. Compounds were extracted as follows: $500 \mu \mathrm{L}$ of Milli-Q water was added and the agar was crushed and centrifuged for $5 \mathrm{~min}$ at $10000 \times \mathrm{g}$. The supernatant was filtered on a $0.22 \mathrm{~mm}$ membrane filter and analyzed by capillary zone electrophoresis (CZE) and MEKC.

\section{Isolation of siderophores by IMAC}

HiTrap $^{\mathrm{TM}}$ Chelating HP Columns kit from GE Healthcare - formerly Amersham (Uppsala, Sweden) was used for IMAC experiments, as follows. The IMAC column was conditioned by addition of Milli-Q water followed by $0.5 \mathrm{~mL}$ of $\mathrm{Fe}_{2}\left(\mathrm{SO}_{4}\right)_{3} 0.1 \mathrm{~mol} \mathrm{~L}^{-1}$ solution. The column was rinsed with water twice and then $10 \mathrm{~mL}$ of starting buffer, which contained $10 \mathrm{mmol} \mathrm{L}^{-1}$ of imidazol and $20 \mathrm{mmol} \mathrm{L}^{-1}$ of sodium phosphate ( $\mathrm{pH}$ 7.4-7.6). The sample was loaded (ca. $500 \mu \mathrm{L}$ ) and the column was flushed with $10 \mathrm{~mL}$ of starting buffer. Fractions of $1 \mathrm{~mL}$ were collected. Elution was carried out with $10 \mathrm{~mL}$ of EDTA $0.05 \mathrm{~mol} \mathrm{~L}^{-1}$, which was also fractioned in $1 \mathrm{~mL}$ aliquots. All IMAC fractions were analyzed by MEKC and electrospray-MS.

\section{Electrophoretic Analysis}

The background electrolyte (BGE) consisted of $25 \mathrm{mmol} \mathrm{L}^{-1}$ phosphate buffer and the $\mathrm{pH}$ varied from 3 to 11.5, for method development. In MEKC experiments, sodium dodecyl sulfate was used as surfactant at $50 \mathrm{mmol} \mathrm{L}^{-1}$. Analyses were carried out in a HP3DCE equipment with a diode array detector (Agilent, Waldbroon - Germany). Capillary conditioning was carried out daily with the following solutions: $\mathrm{NaOH} 1 \mathrm{~mol} \mathrm{~L}^{-1}(5 \mathrm{~min})$; $\mathrm{NaOH} 0.1 \mathrm{~mol} \mathrm{~L}^{-1}(5 \mathrm{~min})$; Milli-Q water (5 min) and BGE (10 min). After each run, the capillary was rinsed for $2 \mathrm{~min}$ with BGE solution. Applied potential varied from 15 to $25 \mathrm{kV}$ and detection wavelength was set at $200 \mathrm{~nm}$, while the full spectra data ranged from 200 to $600 \mathrm{~nm}$. Capillary dimensions are described in the Figures. Electroosmotic flow was determined with acetone - a neutral marker. The electropherograms were analyzed in the HP3DCE ChemStation System software.

\section{Mass Spectrometry Analysis}

Acetonitrile:water (50:50) was used to introduce the sample (make-up liquid) into the equipment. For negative electrospray ionization mode (ESI-) analyses the make-up liquid contained $0.1 \%(\mathrm{v} / \mathrm{v})$ of ammonia while for positive mode (ESI+), ammonia was substituted for $0.1 \%(\mathrm{v} / \mathrm{v})$ of formic acid. The analyses were performed in a Micromass 
Platform LC mass spectrometer (Manchester - United Kingdom), with a single quadrupole mass analyzer. Samples were directly injected with a microsyringe via an injection loop of $5 \mu \mathrm{L}$. A Phoenix 40 syringe pump (CE instruments, Rodano - Italy) introduced the sample and the make-up liquid into the system at $15 \mu \mathrm{L} \mathrm{min}{ }^{-1}$; flow was changed to $100 \mu \mathrm{L} \mathrm{min}^{-1}$ after each analysis for faster system clean up and to avoid carry over. Capillary and cone potential was 3.5 and $25.0 \mathrm{~V}$, respectively. Nitrogen was used as nebulizer gas at $260 \mathrm{~L} \mathrm{~h}^{-1}$. Data was collected in scan mode (from 200 to $1500 \mathrm{Da}$ ) at $1 \mathrm{~Hz}$ and data processing was carried out in the MassLynx software.

\section{Results and Discussion}

\section{CE analysis}

Separation of siderophores from samples not purified by IMAC was not observed in CZE runs (Figure 1). In both evaluated BGEs ( $\mathrm{pH} 7$ and 10), peaks in the negative control and sample presented the same migration times, differing only in peak intensity. An acidic pH BGE was evaluated, although electroosmotic flow (EOF) is extremely low under this condition, making the analysis time unnecessarily long. For this reason, this data was not presented herein. Indeed, as observed in Figure 1, peak migration time in $\mathrm{pH} 7$ was longer than in $\mathrm{pH} 10$, due to reduced ionization of the silanol groups in the capillary wall, which results in decreased EOF.

Since CZE does not separate neutral solutes, the investigated siderophores were either neutral or uncharged in both investigated $\mathrm{pHs}$, as long as the detected peaks presented the same migration time as the EOF marker (data not shown). Thus MEKC seemed to be a better option to analyze these samples.

MEKC analysis showed a different pattern (Figure 2) compared to CZE. The sample and the control could be

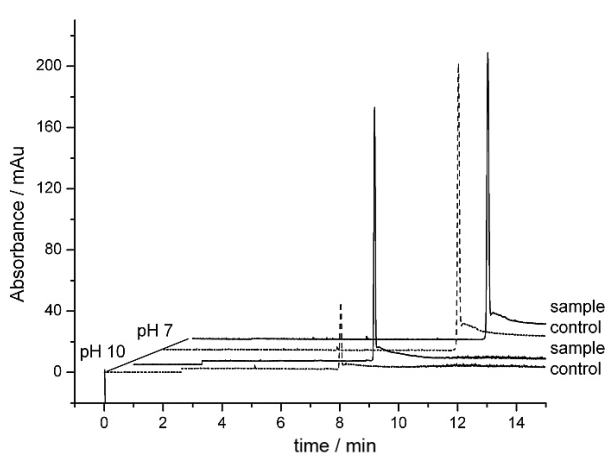

Figure 1. CZE analyses of samples and control for siderophore production, not purified by IMAC. BGE: $25 \mathrm{mmol} \mathrm{L} \mathrm{L}^{-1}$ phosphate buffer; injection time $\left(\mathrm{t}_{\mathrm{i}}\right)$ : $5 \mathrm{~s}(50 \mathrm{mBar})$; applied potential: $15 \mathrm{kV} ; \lambda=200 \mathrm{~nm}$. Capillary length $\left(\mathrm{L}_{\mathrm{r}}\right)=61 \mathrm{~cm}$; effective length $\left(\mathrm{L}_{\text {eff }}\right)=52 \mathrm{~cm}$; internal diameter (i.d.) $=50 \mu \mathrm{m}$. distinguished by peak A. From peak A migration time it is concluded that this solute interacts less with micelle than peak B, thus it is more hydrophilic than the later, under the analysis conditions. Peak B UV-Vis spectra are practically identical in both sample and control, suggesting it is probably the same solute, which could be either a system peak or a compound from the culture medium. Therefore, as expected, these CE runs have proved the sample do contain a substance not present in the control, which probably is the searched siderophore(s).

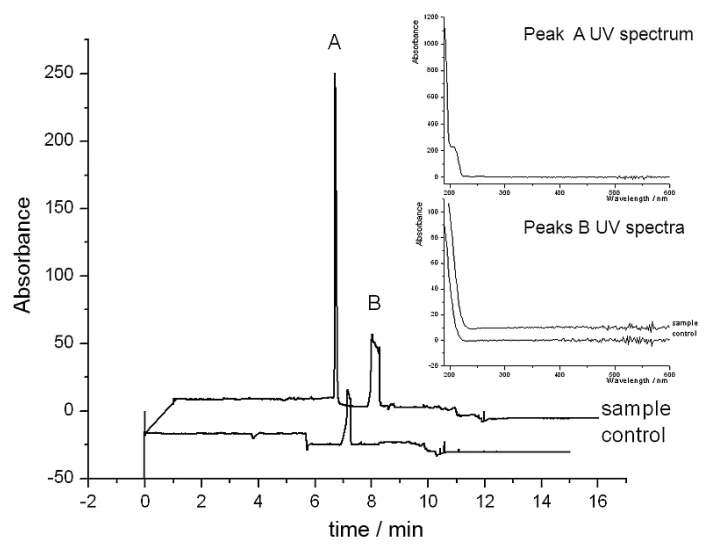

Figure 2. MEKC analyses of control and sample for siderophore production, not purified by IMAC. The insert shows UV-Vis spectra for peaks A and B. BGE: $25 \mathrm{mmol} \mathrm{L}^{-1}$ phosphate buffer at $\mathrm{pH} 10$ plus $50 \mathrm{mmol} \mathrm{L}^{-1} \mathrm{SDS} ; \mathrm{t}_{\mathrm{i}}=5 \mathrm{~s}(50 \mathrm{mBar}) ; \mathrm{V}=25 \mathrm{kV} ; \lambda=200 \mathrm{~nm} ; \mathrm{L}_{\mathrm{t}}=58 \mathrm{~cm}$; $\mathrm{L}_{\text {eff }}=50 \mathrm{~cm}$; i.d. $=50 \mu \mathrm{m}$.

\section{CE analysis - IMAC samples}

In order to selectively isolate the siderophores from the sample, affinity chromatography was applied. The purification of samples extracted from solid plate culture medium was carried out by IMAC. A total of 24 fractions were collected and analyzed by MEKC. Fractions 1 to 16 $(1 \mathrm{~mL}$ each) were obtained from the starting buffer elution and presented the same electrophoretic pattern (fraction 13 - Figure 3) - the other fractions electropherograms are not presented. This fact led us to conclude that no analytes were present in the washing elution fraction (starting buffer), thus reinforcing the idea of selective retention of the siderophores by the IMAC column. By UV-Vis spectra comparison, obtained offline (in the spectrophotometer) and online (in the CE-UV equipment), peak C identity (Figure 3 and Figure 4a) was confirmed to be from imidazol, the main component of the starting buffer. Fractions 17 and 18 were obtained when the eluting buffer (EDTA) was passed through the column. They presented the same color as $\mathrm{Fe}^{3+}$ solution, what strongly suggested the presence of siderophore in these fractions. In fact, 
electropherograms indicated a different peak pattern from the previous 16 fractions (see electropherograms in Figure 3).

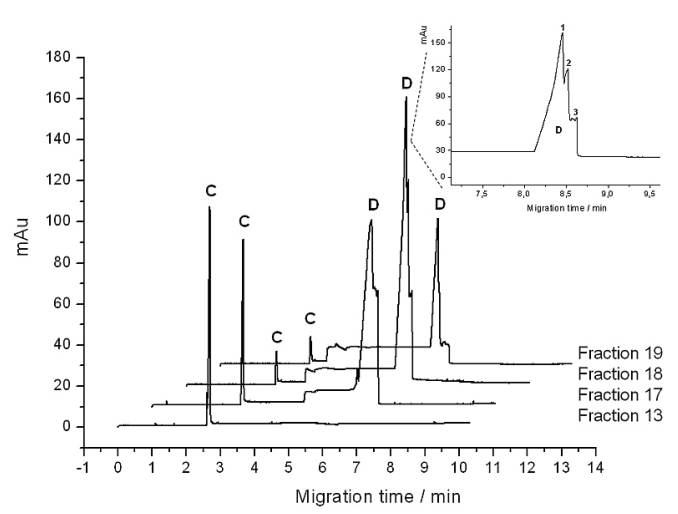

Figure 3. Electrophoretic analyses of IMAC fractions obtained with starting (Fraction 13) and eluting (Fractions 17, 18 and 19) buffers. Electrophoretic conditions are the same as in Figure 2, except for capillary dimensions $\left(\mathrm{L}_{\mathrm{t}}=50 \mathrm{~cm} ; \mathrm{L}_{\text {eff }}=42.5 \mathrm{~cm}\right)$. The insert shows time amplification around peak $\mathrm{D}$.

It seems that at least three peaks were coeluting with peak D in Fraction 18 (Figure 3). This observation is corroborated by their slightly different UV-Vis spectra (Figure 4b). Fractions 17 and 19 showed the same pattern (data not shown). Peak C intensity decreased with eluting buffer passage and its migration time (ca. $2.5 \mathrm{~min}$ ) was almost the same as the one observed in fractions 1 to 16 . A

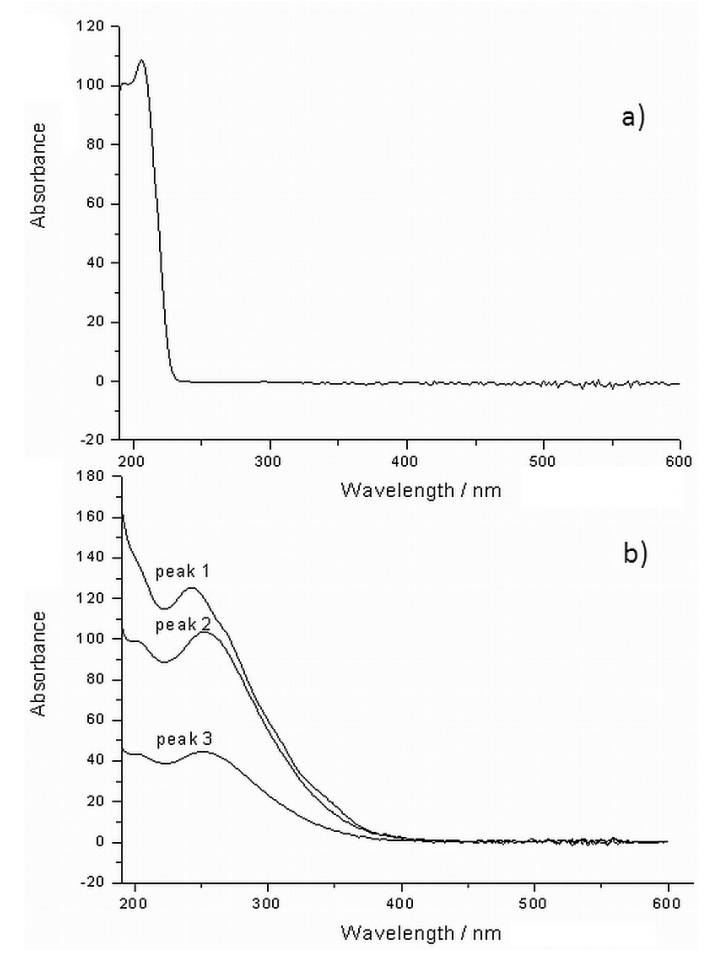

Figure 4. UV-Vis spectra obtained in CE-UV-DAD analysis (Figure 3) for peak $\mathrm{C}$ (a) and for all three slightly separated species in peak D (b). minor difference may be attributed to EOF variation due to sample-to-sample BGE ionic strength variation.

\section{ESI-MS analysis - IMAC samples}

The same fractions obtained by IMAC, and analyzed by CE (MEKC), were analyzed by ESI-MS. Both negative and positive ionization methods were tested and analyses were carried out by direct sample injection.

The fractions obtained with the starting buffer presented the same signals as blank samples (data not shown). However, mass spectra from fractions 17 to 24 demonstrated a different profile, both in negative and positive ionization modes. Nevertheless, negative ionization mode is less informative because signal intensity was low due to poor ion production (Figure 5), suggesting that these samples molecules present a low tendency to donate protons.

Comparison of fraction 18 mass spectra, obtained by negative and positive ionization modes (Figures 5a and $5 \mathrm{~b}$, respectively), shows some signals observed in both of them - with a difference of two mass units (corresponding to $[\mathrm{M}+\mathrm{H}]^{-}$and $[\mathrm{M}-\mathrm{H}]^{+}$, respectively), such as: $m / z 671$ and $673, m / z 658$ and $660, m / z, 737$ and $739, m / z 857$ and 859. However, only peaks $m / z 671$ and 673 presented significant abundance. The CAS dye (605 Da) and the corresponding $\mathrm{Fe}^{3+}$ complex (660.8 Da), which are present in the culture medium, could have been observed in these spectra as the ions $\mathrm{m} / \mathrm{z} 603$ and $658.8\left([\mathrm{M}-\mathrm{H}]^{-}\right)$or $\mathrm{m} / \mathrm{z} 607$ and 663.8 $\left([\mathrm{M}+\mathrm{H}]^{+}\right)$, respectively. Nevertheless, such ions were not present in these spectra, reinforcing the hypothesis that the observed ions are analytes present in the sample.

Focusing on the MS spectrum obtained by ESI+ (Figure 5b), some of the signals may indicate the presence of siderophore. The following ions are possible compounds of interest $\left([\mathrm{M}+\mathrm{H}]^{+}\right) \mathrm{m} / \mathrm{z}$. 726, 876, 952, 1005, 1036 and 1093, since the corresponding sodium adducts $(\mathrm{m} / \mathrm{z} 748,898,974$, 1027,1058 and 1115) were observed as well $\left([\mathrm{M}+23]^{+}\right.$or $\left.[(\mathrm{M}+\mathrm{H})+22]^{+}\right)$. Besides the sodium adducts, the protonated molecular ions $\mathrm{m} / \mathrm{z} 876,1005$ and 1093 also presented possible iron adduct signals $\mathrm{m} / \mathrm{z}, 930,1059$ and 1147 , respectively $\left([\mathrm{M}+55]^{+}\right.$or $\left.[(\mathrm{M}+\mathrm{H})+54]^{+}\right)$, what reinforces the probability of their high affinity for this metal. Indeed, Simionato et al..$^{45}$ investigated Methylobacterium mesophilicum samples by CE-ESI-MS and concluded they produce a siderophore with a relative molecular mass of $1004 \mathrm{Da}$. The Methylobacterium spp. is an endophytic bacterium which interacts with $X$. fastidiosa within the xylem of citrus trees or of grapevines. As a consequence, the endophyte siderophore may be used by $X$. fastidios $a$ for iron uptake, thus resulting in plant disease. ${ }^{44}$ The results observed herein show that grapevine $X$. fastidiosa may also synthesize a similar 


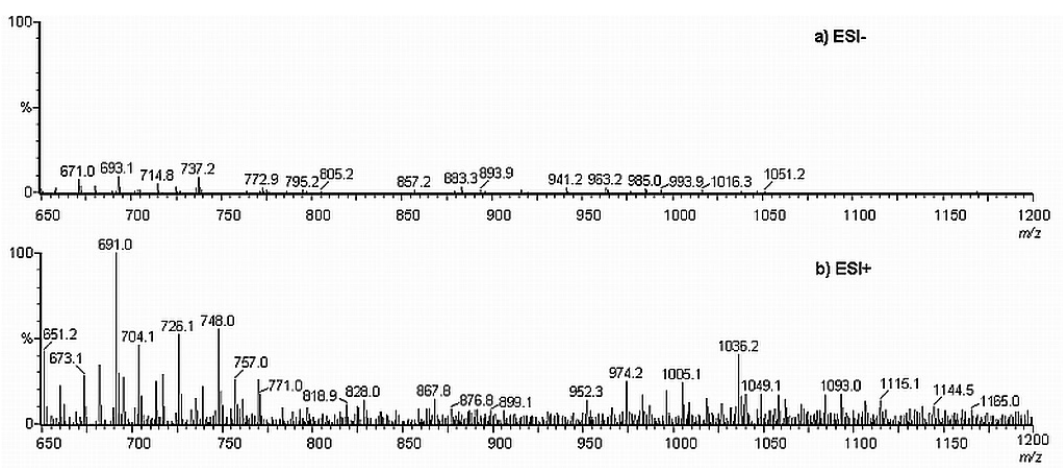

Figure 5. ESI-MS of IMAC fraction 18. (a) Negative electrospray ionization mode. Cone potential: $25 \mathrm{~V}$. ESI potential: $-3.50 \mathrm{kV}$. Make-up liquid: $\mathrm{CH}_{3} \mathrm{CN}: \mathrm{H}_{2} \mathrm{O}(1: 1)$; flow rate: $15 \mu \mathrm{L} \mathrm{min}{ }^{-1}$. Nebulizer gas $\left(\mathrm{N}_{2}\right)$ flow rate: $260 \mathrm{~L} \mathrm{~h}^{-1}$. Source temperature: $100{ }^{\circ} \mathrm{C}$. Ions monitored in scan mode; (b) Positive electrospray ionization mode. ESI potential: $+3.50 \mathrm{kV}$. Other conditions are the same as in a). The MS spectra were subtracted from the blank sample (EDTA).

siderophore, since one of the protonated molecular ions observed in mass spectra presents the same molecular mass.

\section{Conclusions}

Grapevine strain Xylella fastidiosa plate cultures, containing Chrome azurol S solution, have indicated the production of a compound with high affinity by $\mathrm{Fe}^{3+}$ due to halo formation around the bacterial colonies. Analyses of samples extracted from these halos by CZE have shown that this compound was neutral in both basic and neutral $\mathrm{pH}$. In the other hand, MEKC analyses have shown a different profile for the sample and the control. A peak present in the sample, which was not observed in the control by MEKC analysis, refers to a neutral hydrophilic compound, confirming the secretion of a biomolecule from the bacterium isolate. IMAC purification step has corroborated with the hypothesis that this compound has an extremely high affinity for $\mathrm{Fe}^{3+}$. Electrophoretic and mass spectrometry analysis of IMAC fractions indicated the presence of different compounds in the same fractions. Indeed, Fraction 18 electropherogram showed the slight separation of three different species. Mass spectrometry experiments revealed possible siderophores molecular masses, which were identified by blank spectra subtraction and sodium and iron adducts formation. Such biomolecules presented the molecular masses 875, 1004 and $1092 \mathrm{Da}$, which are within the expected range for siderophores molecules. Further investigation is underway for isolation and structural elucidation, to better characterize these compounds.

\section{Acknowledgements}

The authors would like to acknowledge the financial support provided by Fundação de Amparo à Pesquisa do Estado de São Paulo (FAPESP 99/09177-1, 00/12207-9 and 08/57805-2), Coordenação de Aperfeiçoamento de Pessoal de Nível Superior (CAPES) and Conselho Nacional de Desenvolvimento Científico e Tecnológico (573672/2008-3). We also would like to thank Professor Fernando Mauro Lanças by his laboratory facilities.

\section{References}

1. http://www.lbi.ic.unicamp.br/xf/, accessed in March 2009.

2. Liang, X.; Campopiano, D. J.; Sadler, P. J.; Chem. Soc. Rev. 2007, 36, 968.

3. Hartung, J. S.; Beretta, J.; Brlansky, R. H.; Spisso, J.; Lee, R. F.; Phytopathology 1994, 84, 591.

4. Hopkins, D. L.; Mollenhauer, H. H.; Science 1973, 179, 298.

5. Davis, M. J.; Purcell, A. H.; Thomson, S. V.; Science 1978, 199, 75.

6. Davis, M. J.; French, W. J.; Schaad, N. W.; Curr. Microbiol. 1981, 6, 309.

7. Lima, J. E. O.; Miranda, V. S.; Coutinho, A.; Roberto, S. R.; Carlos, E. F.; Fitopatol. Bras. 1996, 21, 392.

8. Chatterjee, S.; Almeida, R. P. P.; Lindow, S.; Annu. Rev. Phytopathol. 2008, 46, 243.

9. Simpson, A. J. G.; Reinach, F.C.; Arruda, P.; Abreu, F. A.; Acencio, M.; Alvarenga, R.; Alves, L. M. C.; Araya, J. E.; Baia, G. S.; Baptista, C. S.; Barros, M. H.; Bonaccorsi, E. D.; Bordin, S.; Bove, J. M.; Briones, M. R. S.; Bueno, M. R. P.; Camargo, A. A.; Camargo, L. E. A.; Carraro, D. M.; Carrer, H.; Colauto, N. B.; Colombo, C.; Costa, F. F.; Costa1, M. C. R.; Costa-Neto, C. M.; Coutinho, L. L.; Cristofani, M.; Dias-Neto, E.; Docena, C.; El-Dorry, H.; Facincani, A. P.; Ferreira, A. J. S.; Ferreira1, V. C. A.; Ferro, J. A.; Fraga, J. S.; Franc,a, S. C.; Franco, M. C.; Frohme, M.; Furlan, L. R.; Garnier, M.; Goldman, G. H.; Goldman, M. H. S.; Gomes, S. L.; Gruber, A.; Ho, P. L.; Hoheisel, J. D.; Junqueira, M. L.; Kemper, E. L.; Kitajima, J. P.; Krieger, J. E.; Kuramae, E. E.; Laigret, F.; Lambais, M. R.; Leite, L. C. C.; Lemos, E. G. M.; Lemos, M. V. F.; Lopes, S. A.; Lopes, C. R.; Machado, J. A.; Machado, M. A.; Madeira, A. M. B. N.; Madeira, H. M. F.; Marino, C. L.; Marques, M. V.; Martins, E. 
A. L.; Martins, E. M. F.; Matsukuma, A. Y.; Menck, C. F. M.; Miracca, E. C.; Miyaki, C. Y.; Monteiro-Vitorello, C. B.; Moon, D. H.; Nagai, M. A.; Nascimento, A. L. T. O.; Netto, L. E. S.; Nhani Jr., A.; Nobrega, F. G.; Nunes, L. R.; Oliveira, M. A.; De Oliveira, M. C.; De Oliveira, R. C.; Palmieri, D. A.; Paris, A.; Peixoto, B. R.; Pereira, G. A. G.; Pereira Jr., H. A.; Pesquero, J. B.; Quaggio, R. B.; Roberto, P. G.; Rodrigues, V.; Rosa, A. J. de M.; De Rosa Jr., V. E.; De Sa’' R. G.; Santelli, R. V.; Sawasaki, H. E.; Da Silva, A. C. R.; Da Silva, A. M.; Da Silva, F. R.; Silva Jr., W. A.; Da Silveira, J. F.; Silvestri, M. L. Z.; Siqueira, W. J.; De Souza, A. A.; De Souza, A. P.; Terenzi, M. F.; Truffi1, D.; Tsai, S. M.; Tsuhako, M. H.; Vallada, H.; Van Sluys, M. A.; Verjovski-Almeida, S.; Vettore, A. L.; Zago, M. A.; Zatz, M.; Meidanis, J.; Setubal, J. C.; Nature 2000, 406, 151.

10. Neilands, J. B.; J. Biol. Chem. 1995, 270, 26723.

11. Hernlem, B. J.; Vane, L. M.; Sayles, G. D.; Water Res. 1999 , 33,951 .

12. Nair, A.; Juwarkar, A. A.; Devotta, S.; J. Hazard. Mater. 2008 , 152, 545.

13. Simionato, A. V. C.; Cantú, M. D.; Carrilho, E.; Microchem. J. 2006, 82, 214.

14. Shanzer, A.; Libman, J.; Weizman, H.; Mester, B.; Hadar, Y.; Chen, Y.; Jurkevitch, E.; Ardon, O.; Pure Appl. Chem. 1996, 68, 757.

15. Braun, V.; Killmann, H.; Trends Biochem. Sci. 1999, 24, 104.

16. Miller, M. C.; Parkin, S.; Fetherson, J. D.; Perry, R. D.; DeMoll, E.; J. Inorg. Biochem. 2006, 100, 1495.

17. Essen, S. A.; Johnsson, A.; Bylund, D.; Pedersen, K.; Lundstrom, U. S.; Appl. Environ. Microbiol. 2007, 73, 5857.

18. Goodell, B.; Jellison, J.; Liu, J.; Daniel, G.; Paszczynski, A.; Fekete, F.; Krishnamurthy, S.; Jun, L.; Xu, G.; J. Biotechnol. 1997, 53, 133

19. Drechsel, H.; Tschierske, M.; Thieken, A.; Jung, G.; Zahner, H.; Winkelmann, G.; J. Ind. Microbiol. 1995, 14, 105.

20. Raymond, K. N.; Carrano, C. J.; Acc. Chem. Res. 1979, 12, 183.

21. Etchegaray, A.; Silva-Stenico, M. E.; Moon, D. H.; Tsai, S. M.; Microbiol. Res. 2004, 159, 425.

22. Payne, S. M.; Methods Enzymol. 1994, 235, 329.

23. Arnow, L. E.; J. Biol. Chem. 1937, 118, 531.

24. Csáky, T. Z.; Acta Chem. Scand. 1948, 2, 450.

25. Schwyn, B.; Neilands, J. B.; Anal. Biochem. 1987, 160, 47.

26. Garcia-Campana, A. M.; Taverna, M.; Fabre, H.; Electrophoresis 2007, 28, 208.

27. Nunnally, B.; Park, S. S.; Patel, K.; Hong, M.; Zhang, X.; Wang, S. X.; Rener, B.; Reed-Bogan, A.; Salas-Solano, O.; Lau, W.; Girard, M.; Carnegie, H.; Garcia-Canas, V.; Cheng, K. C.; Zeng, M.; Ruesch, M.; Frazier, R.; Jochheim, C.; Natarajan, K.; Jessop, K.; Saeed, M.; Moffatt, F.; Madren, S.; Thiam, S.; Altria, K.; Chromatographia 2005, 64, 359.

28. Hernandez-Borges J.; Neususs, C.; Cifuentes, A.; Pelzing, M.; Electrophoresis 2004, 25, 2257.
29. Mucha, P.; Rekowski, P.; Kosakowska, A.; Kupryszewski, G.; J. Chromatogr., A 1999, 830, 183.

30. Berner, I.; Greiner, M.; Metzger, J.; Jung, G.; Winkelmamm, G.; Biol. Metals 1991, 4, 113.

31. Essen, S. A.; Bylund, D.; Holmstrom, S. J. M.; Moberg, M.; Biometals 2006, 19, 269.

32. Cox, G. B.; Gibson, F.; Luke, R. K. J.; Newton, N. A.; O’Brien, I. G.; Rosenberg, H.; J. Bacteriol. 1970, 104, 219.

33. Gledhill, M.; Analyst 2001, 126, 1359.

34. Simionato, A. V. C.; de Souza, G. D.; Rodrigues-Filho, E.; Glick, J.; Vouros, P.; Carrilho, E.; Rapid Commun. Mass Spectrom. 2006, 20, 193.

35. Gaberc-Porekar, V.; Menart, V.; J. Biochem. Biophys. Methods 2001, 49, 335.

36. Hauput, K.; Roy, F.; Vijayalakshmi, M. A.; Anal. Biochem. 1996, 234, 149.

37. Porath, J.; Carlsson, J.; Olsson; I.; Belfrage, G.; Nature 1975, $258,598$.

38. Wimalsena, R. L.; Wilson, G.S.; LC-GC 1992, 10, 223.

39. Sulkowski, E.; Trends Biotechnol. 1985, 3, 1.

40. Ramadan, N.; Porath, J.; J. Chromatogr. 1985, 321, 93.

41. Van Sluys, M A.; De Oliveira, M. C.; Monteiro-Vitorello, C. B.; Miyaki, C. Y.; Furlan, L. R.; Camargo, L. E. A.; da Silva, A. C. R.; Moon, D. H.; Takita, M. A.; Lemos, E. G. M.; Machado, M. A.; Ferro, M. I. T.; da Silva, F. R.; Goldman, M. H. S.; Goldman, G. H.; Lemos, M. V. F.; El-Dorry, H.; Tsai, S. M.; Carrer, H.; Carraro, D. M.; de Oliveira, R. C.; Nunes, L. R.; Siqueira, W. J.; Coutinho, L. L.; Kimura, E. T.; Ferro, E. S.; Harakava, R.; Kuramae, E. E.; Marino, C. L.; Giglioti, E.; Abreu, I. L.; Alves, L. M. C.; do Amaral, A. M.; Baia, G. S.; Blanco, S. R.; Brito, M. S.; Cannavan, F. S.; Celestino, A. V.; da Cunha, A. F.; Fenille, R. C.; Ferro, J. A.; Formighieri, E. F.; Kishi, L. T.; Leoni, S. G.; Oliveira, A. R.; Rosa, V. E.; Sassaki, F. T.; Sena, J. A. D.; de Souza, A. A.; Truffi, D.; Tsukumo, F.; Yanai, G. M.; Zaros, L. G.; Civerolo, E. L.; Simpson, A. J. G.; Almeida, N. F.; Setubal, J. C.; Kitajima, J. P.; J. Bacteriol. 2003, 185, 1018.

42. Silva-Stenico, M. E.; Pacheco, F. T. H.; Rodrigues, J. L. M.; Carrilho, E.; Tsai, S. M.; Microbiol. Res. 2005, 160, 429.

43. Pacheco, F. T. H.; Silva-Stenico, M. E.; Etchegaray, A.; Gomes, J. E.; Carrilho, E.; Tsai, S. M.; Genet. Mol. Biol. 2006, 29, 137.

44. Lacava, P. T.; Silva-Stenico, M. E.; Araújo, W. L.; Simionato, A. V. C.; Carrilho, E.; Tsai, S. M.; Azevedo, J. L.; Pesqui. Agropec. bras. 2008, 43, 521.

45. Simionato, A. V. C.; Simó, C.; Cifuentes, A.; Lacava P. T.; Araújo, W. L.; Azevedo, J. L.; Carrilho, E.; Electrophoresis 2006, 27, 2567.

Received: April 1, 2009 Web Release Date: December 15, 2009

FAPESP helped in meeting the publication costs of this article. 